Int. Archs Allergy appl. Immun. 1981;66:I-VI

\title{
Contents, Vol. 66, 1981
}

Vol. 66,1981

International Archives of Allergy and Applied Immunology

Founded 1950 by D. Harley, P. Kallós, W. Löffler and F.W. Wittich

Continued by E.A. Brown (1952-1954), W. Kaufman (1955-1967), F. Hahn (1961-1972) and

H.C. Goodman (1963-1975)

Edito s-in-Chief

R.R.Å. Coombs, Cambridge

L.A. Hanson, Göteborg

L.M. Lichtenstein, Baltimore, Md.

P. Kallós, Helsingborg

F. Milgrom, Buffalo, N.Y.

Z. Trnka, Basel

G.B. West, Epsom

Contributing Editors

C.J. Abeyounis, Buffalo, N.Y. N.F. Adkinson, Jr., Baltimore, Md. G. Andres, Buffalo, N.Y. E.L. Becker, Farmington, Conn. W.E. Brocklehurst, Windlesham

A. Cerletti, Basel

C.G. Cochrane, La Jolla, Calif.

B. Diamant, Copenhagen

P. Dukor, Basel

L. Edebo, Linköping

W.P. Faulk, Charleston, S.C.

H. Fischer, Freiburg-Zähringen

P.G.H. Gell, Birmingham

H. Gewurz, Chicago, Ill.

I. Glazer, Tel Aviv

R.A. Good, New York, N.Y.

F. Hahn, Wittnau

M. Hess, Bern

L. Hudson, Beckenham

H. Isliker, Lausanne

S.G.O. Johansson, Uppsala

E.A. Kabat, New York, N.Y.

K. Kano, Buffalo, N.Y.

W. Müller-Ruchholtz, Kiel

Ö. Ouchterlony, Göteborg

Z. Ovary, New York, N.Y.

P. Perlmann, Stockholm 
E. Pick, Tel Aviv

M. Plaut, Baltimore, Md.

R.E. Reisman, Buffalo, N.Y.

G. Riethmüller, München

M. Roítt, London

K. Rother, Heidelberg

H.D. Schlumberger, Wuppertal

A. Sehon, Winnipeg

E. Sorkin, Davos Platz

H. Storck, Zurich

A. Szentivanyi, Tampa, Fla.

T.B. Tomasi, Jr., Rochester, Minn.

O. Tönder, Bergen

G. Torrigiani, Geneve

J.L. Turk, London

E.R. Unanue, Boston, Mass.

B.H. Waksman, New Haven, Conn.

A.L. de Week, Bern

G. Wick, Innsbruck

S. Karger $\cdot$ Basel $\cdot$ München $\cdot$ Paris $\cdot$ London $\cdot$ New York $\cdot$ Sydney

Drug Dosage

The authors and the publisher have exerted every effort to ensure that drug selection and dosage set forth in this text are in accord with current recommendations and practice at the time of publication. However, in view of ongoing research, changes in government regulations, and the constant flow of information relating to drug therapy and drug reactions, the reader is urged to check the package insert for each drug for any change in indications and dosage and for added warnings and precautions. This is particularly important when the recommended agent is a new and/or infrequently employed drug.

All rights reserved.

No part of this publication may be translated into other languages, reproduced or utilized in any form or by any means, electronic or mechanical, including photocopying, recording, microcopying, or by any information storage and retrieval system, without permission in writing from the publisher.

S. Karger AG, P.O. Box, CH-4009 Basel (Switzerland) Printed in Switzerland by Buchdruckerei Basler-Zeitung AG, Basel

Contents Vol. 66,1981

No.1

Original Paper

Polyclonal B Cell Activator Associated with Alpha-2-Macroglobulin in the Serum of Patients with Rheumatoid Arthritis

Teodorescu, M.; Chang, J.-L.; Skosey, J.L

Allergenic Relationships of Two Different Antigens of Kentucky Bluegrass Pollen

Chakrabarty, S.; Ekramoddoullah, A.K.M.; Kisil, F.T.; Sehon, A.H 13 
Nonimmune Complexes of Pregnancy-Specific Bi-Glycoprotein Explain Its Heterogeneity Tamsen, L.; Inganäs, M.; Johansson, S.G.O.; Karlsson, T 21

Pregnancy-Associated Alpha-2-Glycoprotein in Recurrent Oral Ulceration and Behçet's Syndrome

Thomson, A.W.; Lehner, T.; Adinolfi, M.; Home, C.H.W 33

RE Migration: An in vitro Phenomenon of Certain Lymphoid Cells Induced by Heterologous Serum

Sandberg, G 40

The Role of Complement and IgG in Zymosan Opsonization

Cheson, B.D.; Morris, S.E 48

Dose Dependence of Trichinella $7 / 8 / \mathrm{ra} / \ll-$ Induced Immunopotentiation

Blackwood, L.L.; Molinari, J.A 55

Nonantibody Binding of Serum Proteins to 5S Anti-Rh Fragments Produced by Chymotrypsin

Waller, M.; Conrad, D.H.; Carlo, J.H 59

Characteristics of and Calcium Requirements for Histamine Release from Rat Peritoneal Mast

Cells

Treated with Concanavalin A

Truneh, A.; Pearce, F.L 68

Effect of Anti-Allergic Compounds on Histamine Release from Rat Peritoneal Mast Cells

Treated with

Concanavalin A

Truneh, A.; Pearce, F.L 76

Metabolic Requirements for Rabbit Polymorphonuclear Leucocyte Lipoxygenase Activity

Walker, J.R.; Parish, H.A 83

Depression of Contact Sensitivity to Oxazolone by the Paramyxo virus of Newcastle Disease.

Impairment

by Infectious Virus of Effector T Cells which Mediate the Response to Contactant

Caruso, G; Palmeri, P.; Dieli, F.; Bellina, L.; Benvegna, S.; Cillari, E.; Salerno, A 91

Similarities of C3b Receptors in Human Kidney and Spleen

Matre, R.; Tönder, $0 \quad 100$

T-Lymphocyte Subpopulations in Patients with Chronic Dermatophytosis

Petrini, B.; Kaaman, T 105

Short Communications

Some Anti-Inflammatory Activities of Copper Complexes of Amino Acids

West, G.B 110

Immune Tolerance Produced by Pre- and Postnatal Exposure to Dietary Antigens

Pathirana, C; Goulding, N.J.; Gibney, M.J.; Pitts, J.M.; Gallagher, P.J.; Taylor, T.G

Book Reviews 119

IV Contents

No. 2

Original Paper

Detection of Cell-Surface Antigens in Murine Tumors by a Protein A Immunofluorescence Test

Luis, J.; Merino, F 121

Detection of Shedding of Human Blood Monocyte Fc Receptor during in vitro Culture

Kay, N.E.; Douglas, S.D 131 
Age-Related Reactivity of Lymphocytes from Multiple Sclerosis Patients to Myelin Basic Protein

Wicher, V.; Olszewski, W.; Milgrom, F 136

Detection of Cross-Reactive Allergens in Kentucky Bluegrass Pollen and Six Other Grasses by

Crossed

Radioimmunoelectrophoresis

Chakrabarty, S.; Løwenstein, H.; Ekramoddoullah, A.K.M.; Kisil, F.T.; Sehon, A.H

A New Look at Basophils in Mice

Urbina, C; Ortiz, C; Hurtado, 1 158

Lipopolysaccharide-Induced Autoantibody Response. II. Age-Related Change in Plaque-

Forming Cell

Response to Bromelain-Treated Syngeneic Erythrocytes

Fujiwara, M.; Kariyone, A 161

Lymphokine Production by PHA-Stimulated Human Lymphocytes Is Enhanced by Interferon

Blomgren, H.; Einhorn, S 173

Seasonal Variation of IgE Antibody Specific for Ragweed Antigen E (IgE-a-AgE) from the

Basophil

Surface in Patients with Ragweed Pollenosis

Grammer, L.; Levitz, D.; Roberts, M.; Pruzansky, J.J.; Zeiss, C.R 179

Suppression of IgE Antibody Response by the Fatty Acid-Modified Antigen

Segawa, A.; Sanchez Borges, M.; Yokota, Y.; Matsushima, A.; Inada, Y.; Tada, T 189

IgG4 Antibodies in Egyptian Patients with Schistosomiasis

Iskander, R.; Das, P.K.; Aalberse, R.C 200

T Cell Subpopulations and Their Functions in vitro. A Study in Patients with Alopecia areata and Alopecia universalis

Gu, S.-Q.; Ros, A.-M.; Stedingk, L.-V. von, Thyresson, N.; Wasserman, J 208

Controlled Studies of Intranasal Immunotherapy for Ragweed Pollenosis

Mathews, K.P.; Bayne, N.K.; Banas, J.M.; McLean, J.A., Bacon, J 218

Short Communications

Histamine Release from Isolated and Intact Mast Cells of Rats

West, G.B 225

Immunosuppressive Effects of Tween 80 on Mice

Barnett, J.B 229

Book Reviews 233

Announcement 236

Ezoe/Furuichi/Katoh/Obara

Plate I

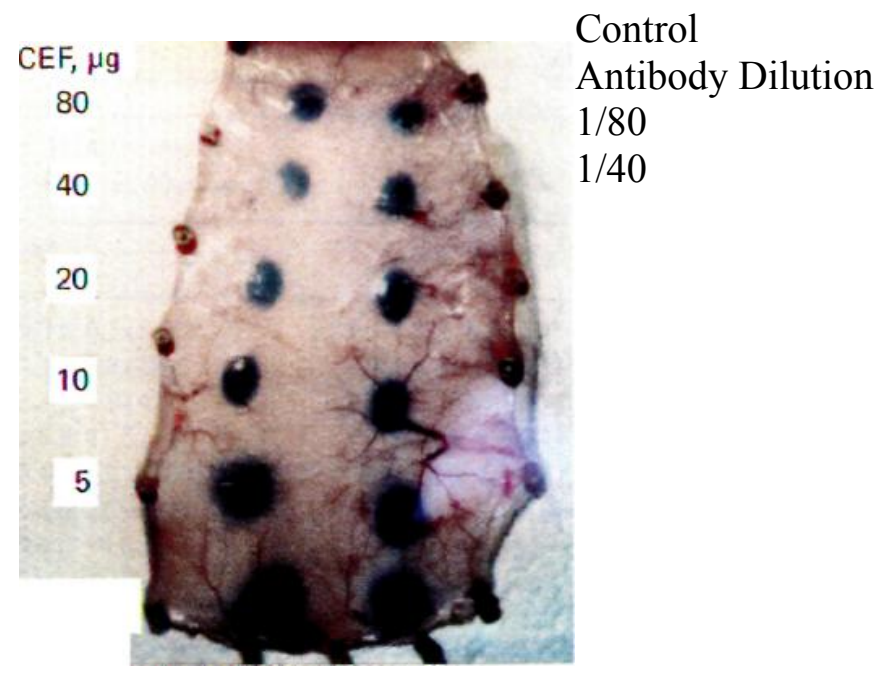




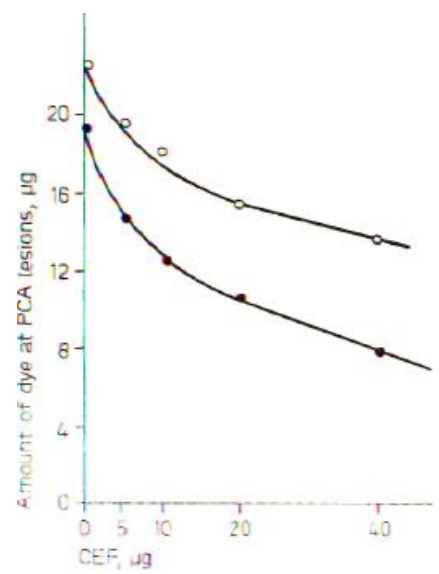

Fig. 1. Inhibition of PCA in rats by local administration of CEF. $2 \mathrm{~h}$ after intracutaneous injections of various amounts of CEF, rats were sensitized with mouse anti-DNP-OVA serum at dilutions of 1:40 (O) and 1:80(»).

International Archives of Allergy and Applied Immunology, Vol. 65, No. 3

S. Karger, Basel

Contents V

No. 3

Original Paper

Regulation of Allergic Reactions by Aerobic Corynebacterium equi Extract, CEF. II. Inhibition of Hete-

rologous PCA and Antigen-Induced Histamine Release in Rats (with 1 color plate)

Ezoe, H.; Furuichi, K.; Katoh, H.; Obara, T. . . 237

Inhibition of in vitro Allogeneic Reactions with Disodium Cromoglycate

Mclntyre, J.A.; Neerunjun, E.D.; Faulk, W.P.; Papamichail, M 244

Anti-Mite IgE Antibody Production in vitro by Peripheral Blood Lymphocytes from Mite-

Sensitive

Atopic Patients

Yanagihara, Y.; Yui, Y.; Shida, T.; Okudaira, H.; Miyamoto, T 251

Role of Antibody in Cytotoxicity by Lymphocytes Armed against 253J Bladder Cancer Line

Catalona, W.J.; Ratcliff, T.L.; McCool, R.E.; Heston, W.D.W 259

Purification of a Human Pancreas-Specific Antigen

Papsidero, L.D.; Abeyounis, C.J.; Milgrom, F.; Van Dusen, L.; Shimano, T.; Ming Chu, T. . .

267 Complement Activation Requirements for Histamine Release from Human Leukocytes:

Influence of

Purified C3ahu and C5ahU on Histamine Release

Hartman, C.T., Jr.; Glovsky, M.M 274

Immunological Properties of Fc Receptor on Lymphocytes. 9. Functional Analysis of FcR $\gamma+$ and $\mathrm{FcR} \gamma-$

Lymphocytes in IgE Antibody Responses

Miyama-Inaba, M.; Masuda, T.; Inada, T.; Takatsu, K.; Hamaoka, T 282

Increased Multiclonal Antibody-Forming Cell Activity in the Peripheral Blood of Patients with SLE

Becker, T.M.; Lizzio, E.F.; Merchant, B.; Reeves, J.P.; Steinberg, A.D 293

Inhibition of the Classical and Alternative Pathways of Human and Guinea Pig Complement by Pyran 
Copolymer

Webster, G.F.; McArthur, W.P 304

Cell-Mediated Immunity in Idiopathic Membranous Nephropathy

Matsumoto, K.; Osakabe, K.; Katayama, H.; Yoshizawa, N.; Harada, M.; Hatano, M 310

Inhibition of Cutaneous Anaphylaxis and Arthus Reactions in the Mouse by Antigen-Specific

$\operatorname{IgA}$

Russell-Jones, G.J.; Ey, P.L.; Reynolds, B.L 316

Suppression of Experimental Allergic Encephalomyelitis by Transfer of Lymph Node Cells from

Lewis

Rats Pretreated with Complete Freund's Adjuvant

Englert, D.; Hempel, K 326

Human Antibodies against Trimellityl Proteins: Comparison of Specificities of $\operatorname{IgG}, \operatorname{IgA}$ and $\operatorname{IgE}$ Classes

Patterson, R.; Roberts, M.; Zeiss, C.R.; Pruzansky, JJ

Migration of Fluoresceinated Pig Lymphocytes in vivo: Technical Aspects and Use in Studies of Auto-

logous and Homologous Cell Survival for up to Three Weeks

Binns, R.M.; Blakeley, D.; Licence, S.T 341

Protective Effect of Sublethal Intraperitoneal Listeria Infection Secondary to Intranasal Influenza Infection in Aged Immunodeficient Mice

Ahlstedt, S.; Sohl-Åkerlund, A 350

Book Reviews 355

356

Announcements

VI Contents

No. 4

Original Paper

Adoptive Transfer of 'Persistent' IgE Responses in Mice in the Absence of Secondary Antigenic Stimulation

Holt, P.G.; Leivers, S.; Batty, J 357

The Use of Modified Cunningham Chambers for the Enumeration of H Rosettes, E Rosettes, and Lymphocyte-Tumour Cell Conjugates

Pross, H.F.; Gallinger, L.A.; Rubin, P.; Baines, M.G 365

T Lymphocyte Subpopulations and Pokeweed Mitogen-Induced Immunoglobulin Synthesis in vitro by

Mononuclear Cells from Psoriasis Patients

Gu, S.-Q.; Ros, A.-M.; Stedingk, L.-V. von; Thyresson, N.; Wasserman, J 372

Antibody Responses in Man after Single or Repeated Treatment with Intramuscular Ampicillin

Ahlstedt, S.; Huitfeldt, B.; Maesen, F.; Månsson, T.; Sjövall, J.; Skoogh, B 382

Delayed-Type Hypersensitivity as Revealed on the Footpads of Mice to Azobenzenearsonate-

Acetyl

Bovine Serum Albumin

Ohuchi, K.; Yoshino, S.; Kurihara, A.; Yoshimura, H.; Ishiguro, M.; Kiso, S.; Tsurufuji, S. . .

391 Regulation of the 'Spontaneous' (Background) Immunoglobulin Synthesis

Benner, R.; Oudenaren, A. van; Haaijman, J.J.; Slingerland-Teunissen, J.; Wostmann, B.S.; Hijmans, W 404 
Anomalous Effects of Disodium Cromoglycate. A Study on Two Secretory Systems

Aim, P.E.; Bloom, G.D.; Henriksson, R 416

Effects of Norepinephrine on Transmembrane Calcium Transport in Rat Mast Cells

Aim, P.E.; Bloom, G.D 427

Immunologic Properties of Conjugates of Ragweed Antigen E with Various Alkoxypolyethylene Glycols

King, T.P.; Weiner, C 439

Enhancement of Mast Cell Differentiation in vitro by T Cell Factor(s)

Ginsburg, H.; Olson, E.C.; Huff, T.F.; Okudaira, H.; Ishizaka, T 447

Antibodies in Human Sera to F(ab')2 Fragments of Monoclonal and Polyclonal IgG

Ling, N.R.; Drysdale, P 459

Short Communication

Inhibition of Human Lung Mast Cell Sensitization by IgE in Allergic Sera

Coleman, J.W.; Godfrey, R.C 464

Book Reviews 467

Author Index 469

Supplement 1

Cellular Interactions in Allergy

13th Symposium of the Collegium Internationale Allergologicum, Konstanz, July 27-31, 1980

Editors: Flemming Kristensen, Bern; Alain L. de Week, Bern; Peter Dukor, Basel 